\title{
Influence of Dietary Supplementary Betaine Hydrochloride on Blood Biochemical Profile in Broilers
}

\author{
D. Desinguraja*, K. Shyama and K. Ally \\ Department of Animal Nutrition, College of Veterinary and Animal Sciences, Mannuthy, \\ Thrissur - 680 651, Kerala, India \\ *Corresponding author
}

\section{A B S T R A C T}

\section{Keywords}

Broiler birds, Betaine hydrochloride, Hematocrit, Biochemical profile

Article Info

Accepted:

12 May 2020 Available Online: 10 June 2020
The study was initiated to examine the effect of dietary supplementation of betaine hydrochloride (betaine $\mathrm{HCl}$ ) on Serum bio chemistry in broiler chicken. The experimental feed was formulated according to BIS (1992) specifications and to the control ration $\left(\mathrm{T}_{1}\right)$, feed grade betaine $\mathrm{HCl}$ at $250,500,750 \mathrm{ppm}$ was added respectively to form different rations $\mathrm{T}_{2}, \mathrm{~T}_{3}$ and $\mathrm{T}_{4}$ for different treatment groups. The birds in each group were maintained on their respective ration throughout the experimental period of six weeks. . Four birds from each treatment was randomly selected at six weeks of age to study the haematological parameters. All serum parameters were within the normal range for species. Supplementation of betaine $\mathrm{HCl}$ in different levels did not improve the serum calcium and inorganic phosphorus. The serum total protein and albumin level as well as serum uric acid were similar $(\mathrm{P}>0.05)$ in all treatment groups. There was significant decrease in serum lipid levels triglycerides $(\mathrm{P}<0.01)$ and low density lipoproteins $(\mathrm{P}<0.05)$ among treatment groups but serum total cholesterol, high density lipoproteins, aspartate aminotransferase (AST) and alanine aminotransferase (ALT) were similar $(\mathrm{P}>0.05)$ in all treatment groups.

\section{Introduction}

Betaine is a naturally occurring amino acid derivative found in microorganisms, plants and animals. Many foods such as wheat, shellfish, spinach and sugar beets contain significant amount of betaine. Metabolic role of betaine in the body is primarily as the methyl group donor and it is also an osmolyte that assists in cellular water homeostasis.
Betaine is a zwitterionic quaternary ammonium compound that is also known as trimethylglycine, glycine betaine, lycine, and oxyneurine. It is a methyl derivative of the amino acid glycine with a formula of $\left(\mathrm{CH}_{3}\right)_{3} \mathrm{~N}^{+} \mathrm{CH}_{2} \mathrm{COO}^{-}$and a molecular weight of 117.2, and it has been characterized as a methylamine because of its 3 chemically reactive methyl groups (Yancey et al,. 1982 and Kidd et al,.1997). Zeisel et al. (1994) 
noted that choline act as a methyl donor for the formation of methionine from homocysteine, by being oxidized to betaine.

\section{Materials and Methods}

One hundred - and - ninety two, day-old Vencobb - 400 strain commercial broiler chicks were used as the experimental birds. The birds were allotted to four dietary treatment groups, with four replications of 12 chicks each randomly in a completely randomized design. The experimental feed (in mash form) was formulated using corn and soybean meal as per BIS (1992) specifications. To the control ration $\left(\mathrm{T}_{1}\right)$, feed grade betaine $\mathrm{HCl}$ was added at 250, 500 and $750 \mathrm{ppm}$ to formulate rations $\mathrm{T}_{2}, \mathrm{~T}_{3}$ and $\mathrm{T}_{4}$ respectively, taking special care for proper mixing of betaine $\mathrm{HCl}$. No growth promoting substance were added to any rations.

Approximately $10 \mathrm{ml}$ of blood was collected during slaughter at $42^{\text {nd }}$ day from four birds each belonging to treatment groups fed rations $T_{1}, T_{2}, T_{3}$ and $T_{4}$ from jugular vein in sterilized glass tubes for serological analysis. The collected blood was allowed to clot and centrifuged for 10 minutes at $2000 \mathrm{rpm}$ to separate the serum and stored in deep freezer at $-20^{\circ} \mathrm{C}$ for further analysis. Serum samples were analyzed for total cholesterol, triglycerides, HDL cholesterol, total protein, albumin and globulin by using Semi Automated Biochemical Analyser (Master T). The LDL cholesterol was calculated by Friedewald equation.

Mineral profile serum calcium and phosphorus was estimated by reports of Moorehead and Biggs, 1974 and Miller et al. (1994). Total protein and albumin concentration quantified by standard procedure (Bromocresol green method) (Lowry et al., 1951 and Johnson et al., 1999) respectively. Estimation of lipid profiles total cholesterol (Richmond, 1973), serum triglycerides (Bucolo and David, 1973), HDL (Seigler and $\mathrm{Wu}, 1981$ ) and LDL (Friedewaldet al., 1972) done as method given in parenthesis of researcher. Excretory metabolic profile uric acid concentration by Uricase-PAP method (Lypo CHEK kit) and liver enzymatic profileSerum aspartate aminotransferase (SGOT or AST) and alanine aminotransferase (SGPT or ALT) contents were measured by using Liqui CHEK kit (M/s. Agappe Diagnostics Limited, Ernakulam, Kerala).

The data collected on various parameters were statistically analyzed as per the methods of Snedecor and Cochran (1994) and the means of different experimental groups were also tested by using Duncan's Multible Range Test (DMRT) in SPSS Version 20.0.

\section{Results and Discussion}

The mean values obtained for serum minerals in experimental birds fed four dietary treatments $\mathrm{T}_{1}, \mathrm{~T}_{2}, \mathrm{~T}_{3}$ and $\mathrm{T}_{4}$ were $10.98,10.54$, 10.61 and $10.70 \mathrm{mg} / \mathrm{dl}$ for calcium and 6.27 , $6.33,6.37,6.29 \mathrm{mg} / \mathrm{dl}$ for inorganic phosphorus are presented in Table 1.

The serum biochemical parameters of experimental birds maintained on four dietary treatments $\mathrm{T}_{1}, \mathrm{~T}_{2}, \mathrm{~T}_{3}$ and $\mathrm{T}_{4}$ were $5.15,4.74$, 4.89 and $4.98 \mathrm{~g} / \mathrm{dl}$ for total proteins and 2.87, 2.47, 2.57 and $2.75 \mathrm{~g} / \mathrm{dl}$ for albumin and $2.27,2.27,2.32$ and $2.23 \mathrm{~g} / \mathrm{dl}$ for globulin, $1.27,1.12,1.12$ and $1.27 \mathrm{~g} / \mathrm{dl}$ for $\mathrm{A} / \mathrm{G}$ ratio, $6.00,6.75,6.73$ and $6.73 \mathrm{~g} / \mathrm{dl}$ for uric acid respectively are depicted in Table 2

The serum lipid profile $(\mathrm{mg} / \mathrm{dl})$ of experimental birds belonging to the groups $T_{1}$, $\mathrm{T}_{2}, \mathrm{~T}_{3}$ and $\mathrm{T}_{4}$ were $23.11,18.68,14.95$ and 13.96 for triglycerides, $72.71,69.16,66.57$ and 64.46 for total cholesterol, 29.66, 27.72, 31.31 and 33.63 for HDL cholesterol and 
38.44, 37.70, 32.27 and 28.03 for LDL cholesterol respectively are represented in the Table 3. The liver enzymes (U/L) of experimental birds belonging to treatment groups $\mathrm{T}_{1}, \mathrm{~T}_{2}, \mathrm{~T}_{3}$ and $\mathrm{T}_{4}$ were $255.06,241.96$,
254.85 and 246.49 for aspartate amino transferase (SGOT) and 13.72, 13.04, 12.62 and 13.03 for alanine amino transfrease (SGPT) respectively are presented in Table 4.

Table.1 Table.1 Serum calcium and inorganic phosphorus level of birds maintained on four experimental rations, $(\mathrm{mg} / \mathrm{dl})$

\begin{tabular}{|c|c|c|c|c|c|c|}
\hline \multirow{2}{*}{ Parameters } & \multicolumn{7}{|c|}{ Treatments } \\
\cline { 2 - 7 } & T1 & T2 & T3 & T4 & F value & P value \\
\hline Calcium & 10.98 & 10.54 & 10.61 & 10.70 & & \\
& \pm 0.57 & \pm 0.76 & \pm 0.50 & \pm 0.36 & $0.118^{\text {ns }}$ & 0.948 \\
\hline Inorganic & 6.27 & 6.33 & 6.37 & 6.29 & \\
\hline Phosphorus & \pm 0.16 & \pm 0.10 & \pm 0.19 & \pm 0.19 & $0.066^{\mathrm{ns}}$ & 0.977 \\
& & & & & & \\
\hline
\end{tabular}

${ }^{1}$ Mean of 4 observations with SE ns-non significant $(\mathrm{P}>0.05)$

Table.2 Serum total protein, albumin, globulin, uric acid concentration (mg / dl) and albumin/globulin ratio (\%) of birds maintained on four experimental rations

\begin{tabular}{|l|c|c|c|c|c|c|}
\hline \multirow{2}{*}{ Parameters } & \multicolumn{5}{|c|}{ Treatments } \\
\cline { 2 - 7 } & $\mathrm{T} 1$ & $\mathrm{~T} 2$ & $\mathrm{~T} 3$ & $\mathrm{~T} 4$ & F value & P value \\
\hline Total protein & 5.15 & 4.74 & 4.89 & 4.98 & $1.142^{\mathrm{ns}}$ & 0.372 \\
& \pm 0.19 & \pm 0.15 & \pm 0.18 & \pm 0.11 & & \\
\hline Albumin & 2.87 & 2.47 & 2.57 & 2.75 & $1.259^{\mathrm{ns}}$ & 0.332 \\
\hline Globulin & \pm 0.08 & \pm 0.22 & \pm 0.19 & \pm 0.12 & & \\
\hline Albumin /globulin & 1.27 & 1.12 & 1.12 & 1.27 & $0.495^{\mathrm{ns}}$ & 0.692 \\
\hline ratio & \pm 0.05 & \pm 0.15 & \pm 0.11 & \pm 0.15 & & 0.980 \\
\hline Uric acid & \pm 0.12 & \pm 0.16 & \pm 0.10 & \pm 0.17 & & \\
\hline & 6.00 & 6.75 & 6.73 & 6.73 & $2.813^{\mathrm{ns}}$ & 0.084 \\
\hline
\end{tabular}

${ }^{1}$ Mean of 4 observations with SE 
Table.3 Serum lipid profile of birds maintained on four experimental rations, (mg / dl)

\begin{tabular}{|l|c|c|c|c|c|c|}
\hline \multirow{2}{*}{ Lipid profile } & \multicolumn{7}{|c|}{ Treatments $^{1}$} \\
& $\mathrm{~T} 1$ & $\mathrm{~T} 2$ & $\mathrm{~T} 3$ & $\mathrm{~T} 4$ & $\mathrm{~F}$ value & P value \\
\hline Triglycerides & $23.11^{\mathrm{c}}$ & $18.68^{\mathrm{b}}$ & $14.95^{\mathrm{a}}$ & $13.96^{\mathrm{a}}$ & & \\
& \pm 1.28 & \pm 0.26 & \pm 1.14 & \pm 1.14 & $16.055^{* *}$ & 0.000 \\
\hline Total cholesterol & 72.71 & 69.16 & 66.57 & 64.46 & & \\
& \pm 2.42 & \pm 2.86 & \pm 3.79 & \pm 1.16 & $1.702^{\mathrm{ns}}$ & 0.220 \\
\hline High density & 29.66 & 27.72 & 31.31 & 33.63 & & \\
lipoprotein & \pm 2.02 & \pm 0.72 & \pm 1.00 & \pm 1.43 & $3.297^{\mathrm{ns}}$ & 0.058 \\
\hline Low density & $38.44^{\mathrm{a}}$ & $37.70^{\mathrm{a}}$ & $32.27^{\mathrm{ab}}$ & $28.03^{\mathrm{b}}$ & & \\
lipoprotein & \pm 1.95 & \pm 3.32 & \pm 2.89 & \pm 0.87 & $4.007^{*}$ & 0.034 \\
\hline
\end{tabular}

1Mean of 4 observations with SE

ns - non significant $(\mathrm{P}>0.05)$, ** significant at 0.01 level $(\mathrm{P}<0.01)$

*Means bearing different superscripts within same column differ significantly $(\mathrm{P}<0.05)$

Table.4 Serum aspartate amino transferase (SGOT) and alanine amino transferase (SGPT) levels of birds maintained on four experimental rations, (U/L)

\begin{tabular}{|l|c|c|c|c|c|c|}
\hline \multirow{2}{*}{ Parameters } & \multicolumn{5}{|c|}{ Treatments } \\
\cline { 2 - 7 } & $\mathrm{T} 1$ & $\mathrm{~T} 2$ & $\mathrm{~T} 3$ & $\mathrm{~T} 4$ & $\mathrm{~F}$ value & $\mathrm{P}$ value \\
\hline $\begin{array}{l}\text { Aspartate } \\
\text { amino } \\
\text { transferase }\end{array}$ & 255.06 & 241.96 & 254.85 & 246.49 & & \\
(SGOT) & \pm 11.57 & \pm 5.49 & \pm 24.18 & \pm 11.97 & $0.187^{\mathrm{ns}}$ & 0.903 \\
\hline $\begin{array}{l}\text { Alanine amino } \\
\text { transferase }\end{array}$ & 13.72 & 13.04 & 12.62 & 13.03 & & \\
(SGPT) & \pm 0.68 & \pm 0.57 & \pm 0.16 & \pm 0.23 & $0.963^{\mathrm{ns}}$ & \\
\hline
\end{tabular}

${ }^{1}$ Mean of 4 observations with SE

$n s-$ non significant $(\mathrm{P}>0.05)$

The values of serum calcium and phosphorus concentration of broilers in the present study were within the normal range reported for the species and comparable with the values reported by Silva et al. (2007) and no difference $(\mathrm{P}<0.05)$ in serum calcium and phosphorus concentration among various treatment groups fed different levels of betaine HCL supplementation.

During the present study serum protein profile (total protein, albumin, globulin and $\mathrm{A} / \mathrm{G}$ ratio) and uric acid concentrations of birds maintained on four experimental rations were not influenced by the different levels of betaine $\mathrm{HCl}$ supplementation, and the values were within the normal range prescribed for the species.

Similarly Attia et al. (2005) and Konca et al. (2008) could not observe any significant effect on the serum protein levels with betaine supplementation in the broiler diet.

On the other hand Hassan et al. (2005), EIHusseiny et al. (2007) and Rao et al. (2011) in slow growing chicken and in the broiler chicken, respectively reported that betaine supplementation caused significantly higher serum protein levels while reduction in serum 
uric acid levels was reported by Zhan et al. (2006) in birds fed methionine deficient broiler diet supplemented with betaine supplementation.

The result on serum triglyceride revealed significant $\quad(\mathrm{P} \leq 0.01) \quad$ difference between groups fed four treatment rations. $\mathrm{T}_{1}$ (control) rations fed birds had significantly higher serum triglyceride than those fed rations $\mathrm{T}_{2}$, $T_{3}$ and $T_{4}$, but those fed $T_{3}$ and $T_{4}$ rations recorded lowest triglycerides and significantly differed from those fed $\mathrm{T}_{1}$ and $\mathrm{T}_{2}$ rations.

Statistical analysis of data on serum total cholesterol and HDL cholestrol revealed no difference between treatment groups. The treatment group fed $\mathrm{T}_{4}$ rations had significantly lower $(\mathrm{P} \leq 0.05)$ serum $\mathrm{LDL}$ cholesterol than the all other treatment groups but at the same time there was no difference between treatment groups fed $T_{1}, T_{2}$ and $T_{3}$ rations.

This is in agreement with the results of Jahanian and Rahmani (2008) who reported that betaine supplementation as a replacement for choline in broiler diets did not affect plasma levels of cholesterol and low density lipoproteins (LDL) but, resulted in significant decrease in plasma triglycerides and very low density lipoproteins and significant increase in high density lipoproteins.

EI-Husseiny et al., (2007) indicated elevated levels of total lipids with increasing levels of betaine at $0.5,0.75$ or $1.0 \mathrm{~g} / \mathrm{kg}$ of broiler diet but was contradictory with report of Maghoul et al. (2009) and Baghaei et al. (2011) who reported no significant effect on blood parameters like cholestrol, triglycerides, LDL, VLDL and HDL with betaine supplementation by replacement of choline and low methionine diet, respectively.

On statistical analysis of data on the above liver enzymes revealed no significant difference $(p>0.05)$ between treatment groups. Attia et al. (2005) and Konca et al. (2008) in their study found that serum alanine amino transferase level in blood of birds was decreased when they were fed with diets supplemented with betaine.

There was no significant difference between treatment groups in serum minerals, protein and uric acid excretory profile. As per mentioned results suggest that there is no role of betaine in the above standard profile. (Table $1 \& 2$ )

The serum lipid profile $(\mathrm{mg} / \mathrm{dl})$ of experimental birds fed rations $T_{1}, T_{2}, T_{3}$ and $T_{4}$ were $23.11,18.68,14.95$ and 13.96 for triglycerides, 72.71, 69.16, 66.57 and 64.46 for total cholesterol, 29.66, 27.72, 31.31 and 33.63 for HDL cholesterol and 38.44, 37.70, 32.27 and 28.03 for LDL cholesterol, respectively.

On statistical analysis, it was found that the triglycerides level of birds supplemented with betaine $\mathrm{HCl}$ at $750 \mathrm{pppm}$ were significantly lower $(\mathrm{P}<0.01)$ than the unsupplemented group. The LDL cholesterol level in serum was significantly lower $(\mathrm{P}<0.05)$ for birds fed with betaine $\mathrm{HCl}$ at $750 \mathrm{ppm}$ than the unsupplemented group. However Statistical analysis of data on serum total cholesterol and HDL cholesterol revealed no significant difference $(\mathrm{P}>0.05)$ between treatment groups. There was no significant difference (P> 0.05) among treatment groups for SGOT and SGPT.

It is concluded clearly the supplementation of betaine $\mathrm{HCl}$ at $750 \mathrm{ppm}$ in the diet decreased the serum triglycerides, serum LDL cholesterol and breast muscle cholesterol content, hence, the supplementation of betaine $\mathrm{HCl}$ can be exploited the betaine involvement in lipid metabolism. There is a real challenge of betaine $\mathrm{HCl}$ to decrease the both blood and breast muscle cholesterol. 


\section{References}

Attia, Y.A., Hassan, R.A., Shehatta, M.H. and Abd EI-Hady, S.B. 2005. Growth, carcass quality and serum constituents of slow growing chicks as affected by betaine addition to diets containing 2. Different levels of methionine. Int. J. Poult. Sci., 4 (11): 856-865

Baghaei. M., Eslami, M., Chaji, M., Mamoue, M. and Bojarpour, M. 2011 Effect of different levels of DL-Methionine replaced with betafin on some of blood parameters on broiler chicken. J. Anim. Vet. Adv., 10 (6): 777-779

Bucolo, G. and David, H. 1973. Quantitative determination of serum triglycerides by the use of enzymes. Clin. Chem., 19: 476482.

El-Husseiny, O.M., El-Ella, A.M.A., AbdElsamee, M.O. and Magda, M. AbdElfattah, 2007. Response of broilers performance to dietary betaine and folic acid at different methionine levels. Int. J. Poult. Sci., 6 (7): 515-523

Friedewald, W.T., Levy, R.I. and Fredrickson, D.S. 1972. Estimation of the concentration of low density lipoprotein cholesterol in plasma, without the use of preparative centrifuge. Clin. Chem.,18: 499-502.

Hassan, R.A., Attia, Y.A. and EI-Ganzory, E.H. 2005. Growth, carcass quality and serum constituents of slow growing chicks as affected by betaine addition to diet containing 1. Different levels of methionine. Int. J. Poult. Sci., 4 (11): 840850

Johnson, A.M., Rohlfs, E.M. and Silverman, L.M. 1999. Proteins, In Tietz. Textbook of clinical chemistry. ( $3^{\text {rd }}$ edn.). Burtis, C.A. and E. R., Eds. W.B. Saunders, Philadelphia. 477 - 540.

Kidd, M. T., Ferket. P.R. and Garlich., J.D. 1997. Nutritional and osmoregulatory functions of betaine. Wld. Poult. Sci. J., 53: $125-139$.

Konca, Y., Kirkpinar, F., Mert, S. and Yaylak, E. 2008. Effect of betaine on performance, carcass, bone and blood characteristics of broilers during natural summer temperatures . J. Anim. Vet. Adv., 7 (8): 930-937

Lowry, O.H., Rosebrough, N.J., Farr, A.L. and Randall, R.J. 1951. Protein measurement with the folin phenol reagent. J. Biol. Chem., 193:265-275.

Maghoul, M.A., Moghadam, N.H., Kermanshahi, H., and Mesagaram, D.M. 2009. The different levels of choline and betaine on broilers performance and carcass characteristic. J. Anim. Vet. Adv., 8 (1): $125-128$

Miller, G.W. 1994. Mineral and bone metabolism, In Textbook of clinical chemistry.( $3^{\text {rd }}$ ed.). Eds Burtis, C.A. and Ashwood, E.R. W.B. Saunders, Philadelphia, pp: 1395-1457.

Moorehead, W.R. and Biggs, H.G. 1974. 2 amino - 2- methyl - 1 - propanol as the alkalizing agent in an improved continuous-flow cresolphthalein complexone procedure for calcium in serum. Clin. Chem., 20: 1458-1460.

Rao, R.S.V., Raju, M.V.L.N., Panda, A.K., Saharia, P. and Sunder, S.G. 2011. Effect of supplementing betaine on performance, carcass traits and immune responses in broiler chicken fed diets containing different concentrations of methionine. Asian-Aust. J. Anim. Sci 24 ( 5 ) : 662 669

Richmond, W. 1973. Use of cholesterol oxidase for assay of total and free cholesterol in serum by continuous - flow analysis. Clin. Chem., 22: 1579-1588.

Seigler, L. and Wu, W.T. 1981. Separation of serum high-density lipoprotein for cholesterol determination: ultracentrifugation vs precipitation with sodium phosphotungstate and magnesium chloride. Clin. Chem., 27: 838-841.

Silva, P.R.L., Freitas N.O.C., Laurentiz, A.C., Junqueira, O.M. and Fagliari, J.J. 2007. Blood Serum Components and Serum Protein Test of Hybro-PG Broilers of Different Ages. Brazilian. J. Poult. Sci., 9 (4): 229-232. 
Yancey, P.H., Clark, M. E., Hand, S.C., Bowlus, R. D. and Somero, G. N. 1982. Living with water stress: Evolution of osmolyte systems. Science. 217: 12141222.

Zeisel, S. H. 1994. Choline and Human Nutrition. Annu. Rev. Nut., 14: 269-296.
Zhan, X.A., Li, J.X., Xu, Z.R. and Zhao, R.Q. 2006. Effect of methionine and betaine supplementation on growth performance, carcass composition and metabolism of lipids in male broilers. Br. Poult. Sci., 47: 576-580.

\section{How to cite this article:}

Desinguraja, D., K. Shyama and Ally, K. 2020. Influence of Dietary Supplementary Betaine Hydrochloride on Blood Biochemical Profile in Broilers. Int.J.Curr.Microbiol.App.Sci. 9(06): 4215-4221. doi: https://doi.org/10.20546/ijcmas.2020.906.494 